\title{
Relationship of Emotional Intelligence, Workplace Spirituality and Performance
}

\author{
S. Bhavaneswari, P. Jagadeesan, P. Balaji
}

\begin{abstract}
The main objective of this research is to examine the influence of emotional and spiritual intelligence on the performance of selected IT employees working in Chennai city. Spiritual intelligence also makes every individual more concerned with other and the accepted surroundings. Self-Awareness, Self-Regulation and Self-Competence are the construct under Emotional Intelligence. The study population comprised the employee of IT sector at Chennai region. The required sample size was initially arrived by conduction pilot survey. From the pilot study the sample size estimated was 381 and which was collected through stratified random sampling method. The Analysis of Confirmatory Factor was conducted to acquire a measurement model for the research and also to confirm the factor structure identified in the EFA analysis in view to simplify the relationship between observed measures and latent variables. The result indicated that there is no effect between the self-regulatory and self-competence and workplace spirituality and self-awareness on work performance. The results of the study indicate that the spiritual intelligence in IT employees affect the increase or decrease in the job performance of their work place.
\end{abstract}

Keywords : Emotional Intelligence, Spirituality, Work Performance, Self-Awareness, Self-Regulation, Self-Competence.

\section{INTRODUCTION}

$\mathrm{P}$ erformance is the effect of work achieved by an individual based on job requirements. Performance can be interpreted of individual expression in achieving institutional objectives (Pritchard, \& Karasick, 1973; Schmidt, \& et al., 1986; Walumbwa\& et al., 2008).The internal factors as well as the external factors affect a person's performance (Law, M\& et al., 1996). Performance employees can influence by some internal factors that are emotional intelligence, spiritual intelligence, and work motivation (Tischler\& et al., 2002; Gundlach\& et al., 2003; Lam., \& O'Higgins, 2012; Kaur, D\& et al., 2013). Spiritual intelligence also makes every individual more concerned with other (Tischler, \& et al., 2002; Luckcock, 2008) and the accepted surroundings. The more the spiritual intelligence crazed, the individual will not lose the values of life,

Revised Manuscript Received on December 05, 2019.

* Correspondence Author

S. Bhavaneswari*, Ph.D. Research Scholar, Department of Commerce, VELS Institute of Advanced Studies, Technology and Science (VISTAS), Chennai, India.

Dr. P. Jagadeesan, Professor and Head, Department of Commerce, VELS Institute of Advanced Studies, Technology and Science (VISTAS), Chennai

Dr. P. Balaji, Assistant Professor, P.G and Research Department of Commerce, Guru Nanak College (Autonomous), Chennai, India. sympathy, and also empathy in him. Spirituality as reported by most researchers is relatedness to self, other's and more power. It is said that what one does on the world should be significant and beneficial for everyone, the institution, and the society.

According to Goleman (2000) Emotional intelligence has $80 \%$ of a individual's success factor, remaining $20 \%$ is determined by IQ. It indicated that there are emotional factors that affect an individual in dealing with an organization. Some emotional factors are howthe person regulates his emotions, and how the person takes a decision with positive emotions. An Individual with high Emotional Intelligence has the capability to deal with people and situations with a optimistic attitude towards all aspects of life and has the capacity to command respect by connecting relationships. Besides intellectual emotional intelligence, there is moreover spiritual intelligence that helps an individual in their day to day activities (Goleman \& et al., 2013). The three intelligences are just as significant for a person even though the responsibility is given differently. The intelligence field of all those things that need to believe in them and the role and responsibility of beliefs, ideas and values in their activities. Spiritual intelligence is capable to place an individual's attitude and life in the context of a wider and rich meaning compared with others, spiritual intelligence is the foundation important to enable other intelligences effectively (Hosseini \& et al., 2010).

\section{REVIEW OF LITERATURE}

Sudarsih (2018) analyzed that the pressure of spiritual and emotional intelligence on the performance of the employee of banking in member with inspiration as mediating. His research method is path analysis. His sampling technique used is census and the research sample is 103 employees. His result indicated that emotional intelligence, spiritual intelligence, and graft motivation have a significant and optimistic impact on the performance and the motivation of the employees.

Siti Masitoh and Ketut Sudarma (2019) aimed to examine that the impact of spiritual intelligence, emotional intelligence, on job satisfaction and performance of the employee is prevailing variable. 


\section{Relationship of Emotional Intelligence, Workplace Spirituality and Performance}

Their sample size is 92. Probability sampling with the type proportionate random sampling were used. This research variable is derived from emotional intelligence, spiritual intelligence, employee performance, and job satisfaction. Percentage analysis, multiple linear regression analysis, coefficient of determination using and path analysis were used to analyse the data.

Their results showed that partially spiritual intelligence and emotional intelligence had a positive effect on the performance of the employee, and had a positive and significant impact on job satisfaction.

Siswoyo Haryono (2018) examined the impact of spiritual and emotional intelligence on performance of temporary nurses. The researcher investigated the mediating role of organisational commitment on the association between spiritual and emotional intelligence on the performance of nurses. He collected data from 129 respondents and analysed using the Structural Equation Modelling (SEM) technique using AMOS. Research assists hospital administrators in to improve the temporary performance of nurses through focusing on their organisational commitment.

Soma Kulshrestha and Dr. Tarun Kumar Singhal (2017) investigated spirituality at job and to find out how spirituality develops educator's concert and organisational effectiveness. They introduced some aspects of probable welfare and needs of carrying spirituality into the organisation and provided suggestions for teachers to integrate spirituality positively in institutions. They provide a critical review of the literature on workplace spirituality by examined the fundamental basis of the current trends among teachers at work.

\section{CONCEPTUAL FRAMEWORK}

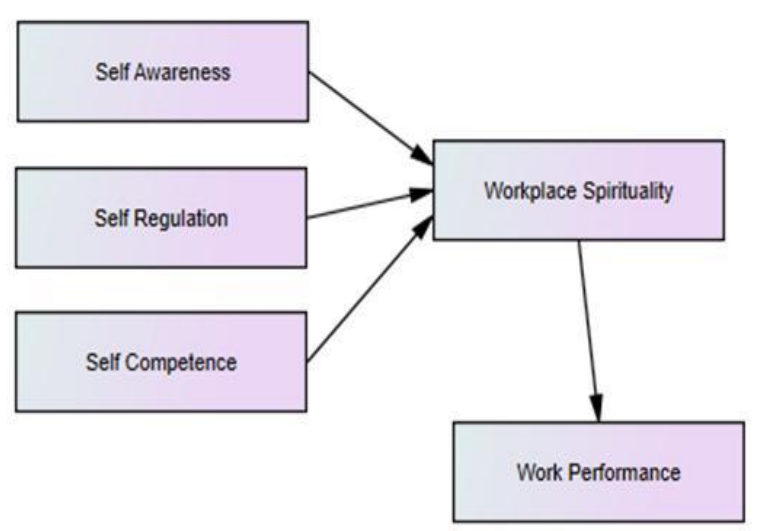

Figure 1: Conceptual Framework

Self-Awareness, Self-Regulation and Self-Competence are the construct under Emotional Intelligence.

Self-awareness is the groundwork of personal development and success. The ability to identify the emotions and found the strengths and limits. Emotional awareness means able to recognize emotions that the workers experience, identify the feelings correlated with the emotion, and recognize the employees think and perform as a result.

Self-regulation is about able to control the emotions and reactions to situations and others. But it is also about feeling optimistic emotions and expressing positive emotions to others. Self-regulation is about to use self-awareness to continue negative reactions under control.

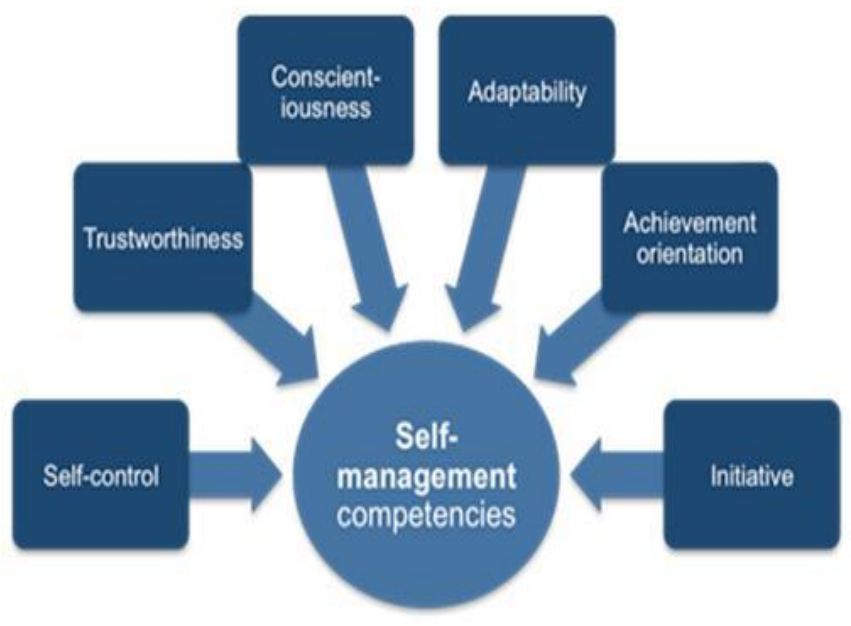

Figure 2: Self Management Competencies Framework

The expansion of the emotional intelligence can be separated into personal and social competencies.

"Personal Competence - self-awareness \& self-management"

"Social Competence - social awareness \& relationship management"

\section{RESEARCH METHODOLOGY}

The study population comprised the worker of IT sector at Chennai region. The required sample size was initially arrived by conduction pilot survey. From the pilot study the sample size estimated was 381 and which was collected through stratified random sampling method. Initially a structured questionnaire was administrated to collect the responses among the IT employee. The responses probed about the Emotional Intelligence explored through Factor Analysis (EFA) and were by three constructs were identified. The identified factors are Self Awareness, Regulation and Competence. There are three exogenous variable namely are Self Awareness, Regulation and Competence. Work Spirituality as mediating variable and Work Performance as endogenous variable. The obtained constructs were tested for Confirmatory Factor Analysis through AMOS 20. A structural equation model was developed and tested through path goal analysis.

\section{RESULT AND DISCUSSION}

Confirmatory Factor Analysis was done to get a measurement model for the research and also to prove the factor structure précised in the EFA analysis in view to clarify the association between observed measures and concealed variables. The modification indices were utilized to improve the model fit. Accordingly, the error terms for some measurement items were covaried to get good fit for the research model. 


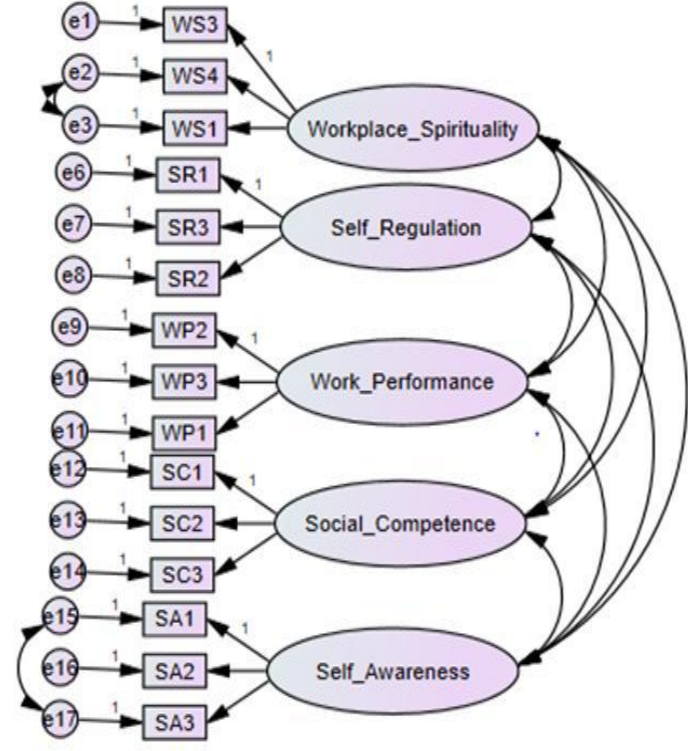

Figure 3: CFA

According to McDonald (2002), CFI, GFI, NFI and the NNFI are generally used fit indices in SEM. The goodness of fit indices derived to get the measurement model; GFI, AGFI, CFI, NFI, RFI, TLI, RMR and RMSEA express sufficient predictive ability present in the model as found in Table 1. Table 1shows the goodness of fit indices of the measurement model for EI.

Table 1: Fit Indices for Measurement Model

\begin{tabular}{|c|c|c|}
\hline Metric & Observed Value & Recommended Thresholds \\
\hline GFI & 0.919 & $\geq 0.90$ \\
\hline AGFI & 0.875 & $\geq 0.80$ \\
\hline NFI & 0.904 & $\geq 0.90$ \\
\hline IFI & 0.928 & $\geq 0.90$ \\
\hline CFI & 0.927 & $\geq 0.90$ \\
\hline TLI & 0.902 & $\leq 0.08$ \\
\hline RMSEA & 0.73 & $\leq 0.05$ \\
\hline RMR & 0.38 & \\
\hline
\end{tabular}

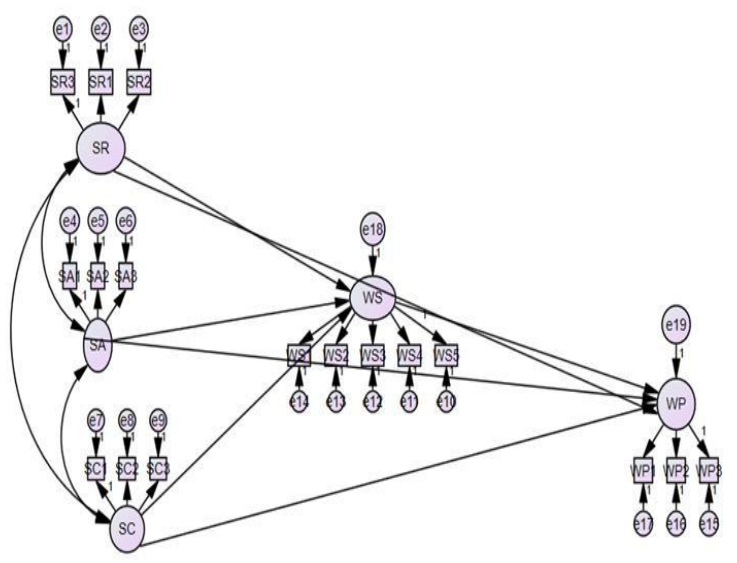

Figure 4: Significance tests of individual parameters
Table - 2: Regression Weights of Workplace Spirituality and Performance

\begin{tabular}{|c|c|c|c|c|c|c|}
\hline & & & Estimate & S.E. & C.R. & P- Value \\
\hline WS & $<--$ & SR & 0.044 & 0.073 & 0.598 & 0.550 \\
\hline WS & $<---$ & SA & 0.133 & 0.063 & 2.097 & $.036 * *$ \\
\hline WS & $<---$ & SC & 0.027 & 0.057 & 0.470 & 0.638 \\
\hline WP & $<---$ & WS & -0.009 & 0.054 & 2.145 & $0.062 *$ \\
\hline WP & $<---$ & SR & 0.307 & 0.072 & 4.273 & $<0.001 * * *$ \\
\hline WP & $<---$ & SA & -0.036 & 0.061 & -0.600 & 0.548 \\
\hline WP & $<---$ & SC & -0.130 & 0.055 & -2.341 & $0.019 * *$ \\
\hline
\end{tabular}

Table 2 shows that self-awareness have significant effect on workplace spirituality $(\mathrm{p}=0.036)$, workplace spirituality have significant effect on work performance $(p=0.062)$, self-regulation have significant effect on work performance $(\mathrm{p}=<0.001 * * *)$ and self-competence have significant effect on work performance $(\mathrm{p}=0.019)$. Whereas self-regulatory and self-competence have no effect on workplace spirituality and self-awareness have no effect on work performance.

\section{IMPLICATIONS AND CONCLUSION}

Emotional intelligence has an important influence with the direction of positive coefficient on job motivation. The results of the study point out that emotional intelligence in IT employees effect the increase or decrease in motivation. The coefficient of spiritual intelligence variables has extensively influence with the direction of positive coefficient on job motivation. The results of this paper elucidate that the spiritual intelligence in workers affect the increase or decrease in motivation. The researcher concluded emotional intelligence significantly affects the way of positive coefficient on IT employee performance. The Researcher indicated that emotional intelligence in employees effect the increase or decrease in the performance of the IT sector. The coefficient of spiritual intelligence variables has significantly control with the direction of optimistic coefficient on employee performance. The results of the study indicate that the spiritual intelligence in IT employees affect the increase or decrease in the job performance of their work place.

\section{REFERENCES}

1. Akhtar, Ghufran, Husnain M. dan Shahid A. (2017). The Effect of Emotional Intelligence on Employee's Job among Business Students in Pakistan. Bulletin of Education and Research.38(01).

2. Cherati, h., Mahdavi, I., \& Rezacian, J. (2013). The mediating role of job satisfaction between Spiritual Intelligence and Organisational Commitment. International Journal of Reserach in Organisational Behaviour and Human Resource Management,1 (1), 1-11.

3. Goleman D (2001) An EI-based theory of Performance.The Emotionally Intelligent Workplace, Jossey-Bass, San Francisco, CA.

4. Goleman, D., Boyatzis, R. E., \& McKee, A. (2013). Primal leadership Unleashing the power of emotional intelligence. Harvard Business Press. 


\section{Relationship of Emotional Intelligence, Workplace Spirituality and Performance}

5. Gundlach, M. J., Martinko, M. J., \& Douglas, S. C. (2003). Emotional intelligence, causal reasoning, and the self-efficacy development process. The International Journal of Organizational Analysis, 11(3), 229-246.

6. Hosseini, M., Elias, H., Krauss, S. E., \& Aishah, S. (2010). A review study on spiritual intelligence, adolescence and spiritual intelligence, factors that may contribute to individual differences in spiritual intelligence, and the related theories. International Journal of Psychological Studies, 2(2), 179.

7. Kaur, D., Sambasivan, M., \& Kumar, N. (2013). Effect of spiritual intelligence, emotional intelligence, psychological ownership and burnout on caring behaviour of nurses: A cross-sectional study. Journal of clinical nursing, 22(21-22), 3192-3202.

8. Khorshidi, A., \& Ebadi, M. (2012). Relationship between Spiritual Intelligence and Job Satisfaction . Journal of Applied Environmental and Biological Sciences ,2 (3), 131-133.

9. Lam, C. S., \& O'Higgins, E. R. (2012). Enhancing employee outcomes: The interrelated influences of managers' emotional intelligence and leadership style. Leadership and Organization Development Journal, 33(2), 149-174.

10. Law, M., Cooper, B., Strong, S., Stewart, D., Rigby, P., \& Letts, L. (1996). The person-environment-occupation model: A transactive approach to occupational performance. Canadian journal of occupational therapy, 63(1), 9-23.

11. Luckcock, T. (2008). Spiritual intelligence in leadership development: A practitioner inquiry into the ethical orientation of leadership styles in LPSH. Educational Management Administration \& Leadership, 36(3), 373-391.

12. Malik, Sania Zahra and Sehrish Shahid. (2016). Effect of Emotional Intelligence on Academic Performance: The Moderating Role of Perceived Organizational Support. Vol 06(3).

13. Pritchard, R. D., \& Karasick, B. W. (1973). The effects of organizational climate on managerial job performance and job satisfaction. Organizational behavior and human performance, 9(1), 126-146.

14. Schmidt, F. L., Hunter, J. E., \& Outerbridge, A. N. (1986). Impact of job experience and ability on job knowledge, work sample performance, and supervisory ratings of job performance. Journal of applied psychology, 71(3), 432.

15. Shahzadi, Irum et al. (2014). The Impact of Employee Motivation on Employee Performance. European Journal of Business and Management. 06(23).

16. Shih, H. A., \& Susanto, E. (2010). Conflict management styles, emotional intelligence, and job performance in public organizations. International Journal of Conflict Management, 21(2), 147-168.

17. Siti Masitoh, Ketut Sudarma.(2019) The Effect of Emotional Intelligence and Spiritual Intelligence on Work Satisfaction with Employee Performance as Intervening Variables. Management Analysis Journal 8 (1) (2019)

18. Tischler, L., Biberman, J., \& McKeage, R. (2002). Linking emotional intelligence, spirituality and workplace performance: Definitions, models and ideas for research. Journal of managerial psychology, 17(3), 203-218.

19. Walumbwa, F. O., Avolio, B. J., \& Zhu, W. (2008). How transformational leadership weaves its influence on individual job performance: The role of identification and efficacy beliefs. Personnel psychology, 61(4), 793-825.

\section{AUTHORS PROFILE}

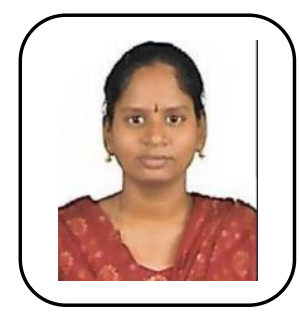

Ms. S. Buvaneswari, is current Ph.D Research Scholar from Department of Commerce, VISTAS, Chennai. She completed my UG degree B.Com in Valliammal College for Women, Anna Nagar, Chennai. She competed her Post - Graduate in Commerce at Madras University, Chennai. She completed my B.Ed., Professional degree in Ponnusamy Nadar College, Ayapakkam, Chennai

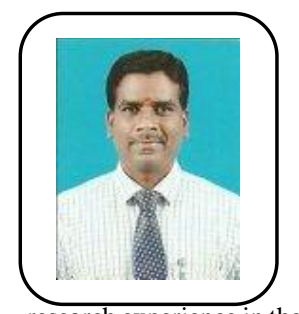

Dr. P. Jagadeesan Ph.D, is currently Professor and Head, Department of Commerce, VELS Institute of Science Technology and Advanced Studies, Chennai, Tamil Nadu, India. He was received doctoral degrees from University of Madras, Chennai and Dravidian University Kuppam, Andhra Pradesh in the field of human resource management and marketing respectively. He has more than two decades of teaching and research experience in the field of human resource management and marketing. He was published many research articles in the national and international journals.

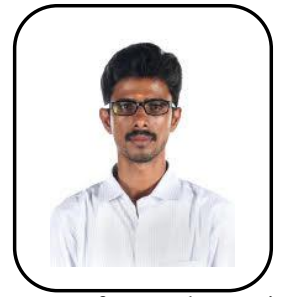

Dr. P. Balaji, Assistant Professor in Post Graduate and Research Department of Commerce, Guru Nanak College (Autonomous), Chennai. He has received Under-Graduation, Post-Graduation, Master of Philosophy and Doctor of Philosophy in Commerce from University of Madras, Chennai. He is the Lime Member of Indian Commerce Association, Indian Accounting Association and Indian Finance Association. He has posses four years of research experience and one year teaching experience in the realm of commerce. He has cleared UGC NET and Tamil Nadu SET in the subject of Commerce. He was specialized in teachings related to Banking, Marketing and Human Resource Management and has research interest in the field of Banking Technology, Marketing Research and Human Resource Development. He has contributed many empirical research articles to various eminent national and international level journals in the field of commerce and management indexed in SCOPUS/UGC CARE listed Journals and also actively participating in various national and international conferences. He has received three best paper awards in various international and national conferences. He is the recipient of UGC Non-NET fellowship from Department of Commerce, University of Madras, Chennai. He was awarded University Research Fellowship from the Department of Commerce, University of Madras, Chennai and received Doctoral Research Fellowship from Institute of Public Enterprise, Hyderabad in collaboration with Indian Council of Social Science Research (ICSSR) for the doctoral thesis awarded from Department of Commerce, School of Business and Management Studies, University of Madras, Chennai. 